\title{
Professionalism: Social media mishaps
}

$\mathrm{T}$ he "add photo" option on Facebook should probably be renamed the "you'll soon regret posting this" button. Actually, social media in general has proven to be a virtual breeding ground of self-induced embarrassment - offensive jokes that seemed funny at the time, off-the-cuff comments made in anger, pictures of drunken tomfoolery that should have been deleted rather than uploaded.

But surely physicians - the bright, highly educated, cautious lot that they are - would never do anything foolish online. Medical professionals are above all this social media shenaniganery. Sure, you can believe that, if you like. If you wish to continue believing it, though, here's a suggestion: Stop reading this article.

It turns out that doctors who use Facebook, Twitter, Blogger, Tumblr or other social media platforms are perfectly capable of embarrassing themselves - and the medical profession as a whole - by posting unprofessional material online. One prominent example, cited in an academic paper about online medical professionalism, involves a group of health care workers, including physicians, who travelled to Haiti to deliver aid ( $J$ Gen Intern Med 2010;25:1227-9). Their good work was overshadowed by Facebook pictures of doctors grinning while holding guns and bottles of alcohol, as well as photos of naked, unconscious patients.

"While it is tempting to view such incidents as rare events, recent research has shown that posting of unprofessional content is common among medical students, residents and other health care providers," the paper states.

Physicians sometimes fail to consider the potential impact of what they say online, the paper suggests, and need to realize that one "momentary lapse in judgment" can tarnish the entire profession. The problem is, traditional principles of medical professionalism can be difficult to apply to online activities. It would not be considered

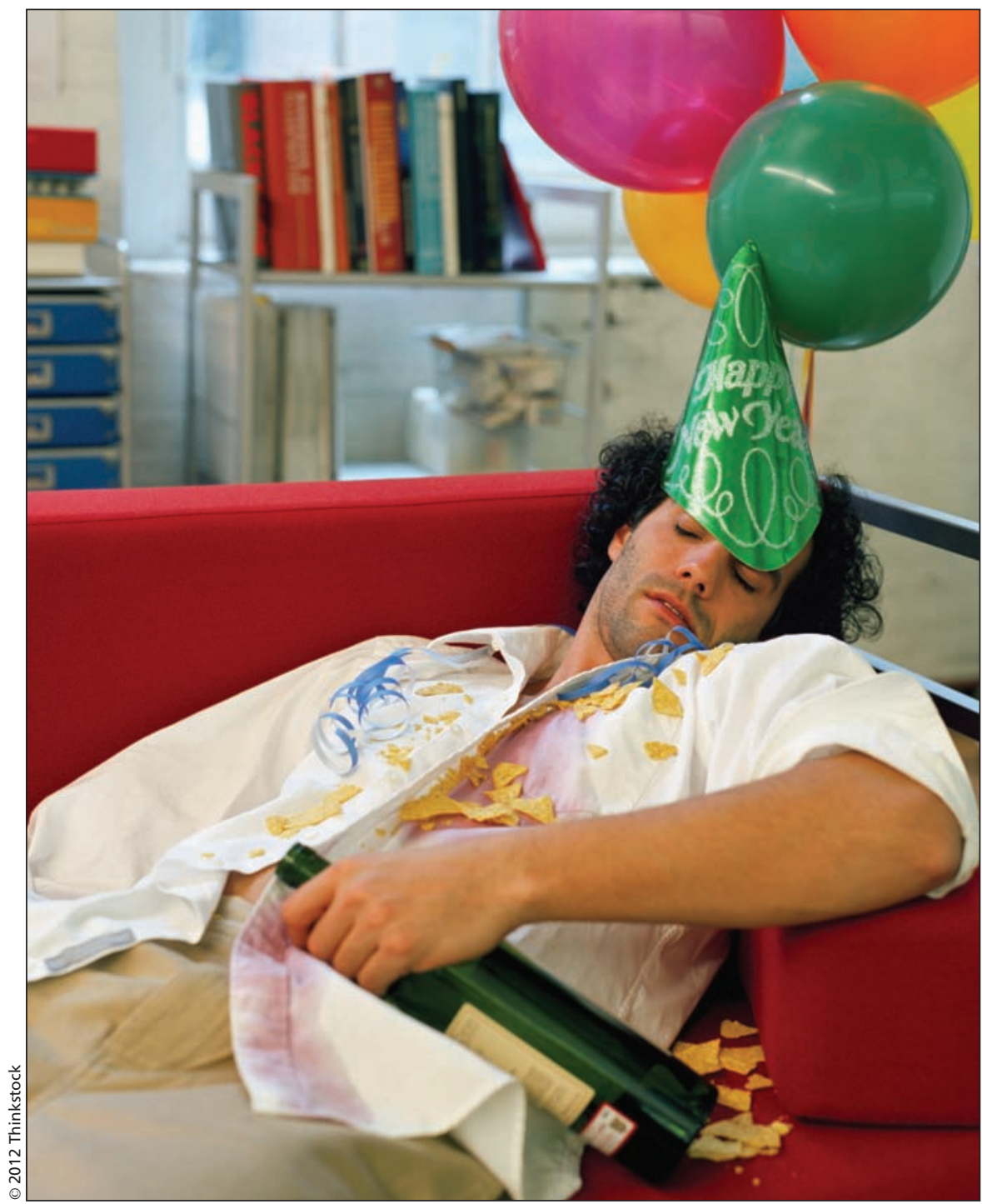

What would you think if you saw this picture on Facebook and realized he was your doctor?

unprofessional, for example, for physicians to drink alcohol during their free time. Yet posting images that even imply intoxication could, if viewed by patients, lead to trust issues.

Another problem is what's referred to as the "online disinhibition effect" - the tendency to behave far differently in online interactions than during face-to-face conversations. Doctors talking with patients, for instance, receive visual feedback on how the information they are providing is being received. A computer monitor, on the other hand, doesn't care if you are coming off as insensitive or unprofessional.

"The context may be missing and there is a lack of visual cues. It becomes a very tricky thing. People act differently online," says Dr. Katherine Chretien, chief of the hospitalist section at the Washington DC, VA [Veterans Affairs] Medical Center and an author of the online professionalism paper.

One of the primary reasons medical professionalism is lagging online is that the doctors who use social media the most are from a different generation 
than those who know the most about maintaining the reputation of the profession. "People who have a blog or are on Twitter and Facebook tend to be on the younger side. People with more wisdom about professional boundary issues tend to be on the older side. There is a bit of a gap there and a lack of training and mentorship in this area," says Dr. David Brendel, a psychiatrist practising in the area of Boston, Massachusetts, and a sought-after educator on matters of medical ethics and professionalism (drdavidbrendel.com).

Youth does indeed appear to be a factor, as indicated by the many social media mishaps perpetuated by medical students. According to a survey led by Chretien, many medical schools in the United States have reported the posting of unprofessional content by their students, including violations of patient privacy, images of illicit drug use and profane or sexually suggestive material (JAMA 2009;302:1309-15). Most violations resulted in warnings, though a few were deemed serious enough to warrant dismissal.

Of course, doctors-in-training have been blowing off steam for years through activities that are far from "pro- fessional," such as putting on crude comedy skits or partying in the fashion typical of university students (hardy, that is). These activities have generally been accepted as a means of coping with the stress of a demanding curriculum. In the Internet age, however, more caution is needed. "When disseminated on mediasharing sites such as YouTube or Google Video, they carry the potential for significant public impact and viral spread of content," the paper states.

To curb the potential harm posed by social media to physicians' reputations, the authors suggest that medical schools, hospitals and group practices set guidelines and standards for online professionalism for their members. Individual physicians, meanwhile, should be more conscious of the fact that as they "tread through the World Wide Web, they leave behind a 'footprint' that may have unintended consequences for them and for the profession at large."

The best cure for online fatuity, however, is a heaping dose of common sense, says Dr. Kevin Pho, who practises internal medicine in Nashua, New Hampshire, and frequently writes about social media on his website (kevinMD.com).
Don't identify patients. Don't rant about colleagues. Don't let your fingers type what your mouth wouldn't dare say. "I have what I call the elevator test," says Pho. "If they wouldn't say it in a crowded hospital elevator, they shouldn't write it on a social network." - Roger Collier, CMAJ

CMAJ 2012. DOI:10.1503/cmaj.109-4209

Editor's note: Sixth in a multipart series on medical professionalism.

Part I: The "good doctor" discussion (www.cmaj.ca/lookup/doi/10.1503/cmaj .109-4200).

Part II: What is it? (www.cmaj.ca /lookup/doi/10.1503/cmaj.109-4211).

Part III: The historical contract (www.cmaj.ca/lookup/doi/10.1503 /cmaj.109-4230).

Part IV: Can it be taught?

(www.cmaj.ca/lookup/doi/10.1503 /cmaj.109-4232).

Part V: Social media outreach (www.cmaj.ca/lookup/doi/10.1503 /cmaj.109-4207). 